\title{
Importance of Burrow-Entrance Mounds of Gunnison's Prairie Dogs (Cynomys gunnisoni) for Vigilance and Mixing of Soil
}

Author(s): Csongor I. Gedeon, Lee C. Drickamer, and Andrew J. Sanchez-Meador

Source: The Southwestern Naturalist, 57(1):100-104. 2012.

Published By: Southwestern Association of Naturalists

DOI: http://dx.doi.org/10.1894/0038-4909-57.1.100

URL: http://www.bioone.org/doi/full/10.1894/0038-4909-57.1.100

BioOne (www.bioone.org) is a nonprofit, online aggregation of core research in the biological, ecological, and environmental sciences. BioOne provides a sustainable online platform for over 170 journals and books published by nonprofit societies, associations, museums, institutions, and presses.

Your use of this PDF, the BioOne Web site, and all posted and associated content indicates your acceptance of BioOne's Terms of Use, available at www.bioone.org/page/terms_of_use.

Usage of BioOne content is strictly limited to personal, educational, and non-commercial use. Commercial inquiries or rights and permissions requests should be directed to the individual publisher as copyright holder. 


\title{
IMPORTANCE OF BURROW-ENTRANCE MOUNDS OF GUNNISON'S PRAIRIE DOGS (CYNOMYS GUNNISONI) FOR VIGILANCE AND MIXING OF SOIL
}

\author{
Csongor I. Gedeon, Lee C. Drickamer,** and Andrew J. Sanchez-Meador \\ Department of Ethology, Eötvös Loránd University, 1117 Budapest, Pázmány Péter sétány 1/c, Hungary (CIG) \\ Department of Biological Sciences, Northern Arizona University, Flagstaff, AZ 86011-5640 (LCD, AJSM) \\ Current address of LCD: 1294 Regent Terrace South, Myrtle Beach, SC 29575 \\ Current address of AJSM: School of Forestry, Northern Arizona University, Flagstaff, AZ 86011-15018 \\ *Correspondent: lee.drickamer@nau.edu
}

\begin{abstract}
Aboveground mounds and underground burrows are multifunctional and influence behavior and habitat of Gunnison's prairie dogs (Cynomys gunnisoni). Four colonies were studied June-September 2004 to examine function of mounds with respect to vigilance for predators, and to estimate magnitude of soil mixed by these prairie dogs. Frequency of vigilance atop mounds increased in taller vegetation and individuals at perimeters of colonies oriented toward the outside more frequently than to the interior of colonies. Mounds accounted for an average of 10,374 $\mathrm{kg}$ of soil/ha that was excavated from the burrow. This mass of subsoil moved to the surface and the $7-17 \mathrm{~m}^{3}$ of air in the burrow make the geomorphic effect of prairie dogs potentially significant.

RESUMEN-Montículos de tierra construidos en la superficie y madrigueras construidas bajo tierra tienen muchas funciones y afectan el comportamiento y el hábitat de los perritos de las praderas de Gunnison (Cynomys gunnisoni). Cuatro colonias fueron estudiadas de junio a septiembre del 2004 para examinar la función de los montículos con relación a la vigilancia contra depredadores, y para calcular la cantidad de tierra mezclada por estos animales. La frecuencia de los comportamientos de vigilancia encima de los montículos aumentó en vegetación más alta, y los animales en los márgenes de las colonias se orientaron hacia afuera más frecuentemente que hacia el interior de las colonias. Los montículos contuvieron un promedio de $10,374 \mathrm{~kg}$ de tierra/hectárea excavada de las madrigueras. Esta cantidad de tierra transportada a la superficie, y los $7-17 \mathrm{~m}^{3}$ del aire en la madriguera, indican que el efecto geomórfico de los perritos de la pradera puede que sea considerable.
\end{abstract}

Prairie dogs (Cynomys) dig burrows that serve numerous functions, e.g., protection from the environment, defense from predators, as a place to store food, hibernation, and reproduction (Pizzimenti and Hoffmann, 1973; Meadows, 1991). During burrowing, subsoil is mixed and deposited at the opening, which results in bare, loose mounds that increase heterogeneity of habitats (Whitford and Kay, 1999). Mounds also protect against flooding. Black-tailed prairie dogs (C. ludovicianus) use mounds as vantage points to scan for predators or conspecifics (King, 1955, 1959).

Vigilance behavior comprises a significant part of aboveground behavior of prairie dogs (Longhurst, 1944); its frequency varies between pre-juvenile and post-juvenile periods (Verdolin and Slobodchikoff, 2002) and by location within the colony (Armitage, 1962; Svendsen, 1974; Hoogland, 1979). Relatively high mounds and low vegetation facilitate better detection of predators and receiving visual signals from conspecifics.
Whether taller vegetation is protective or obstructive for prairie dogs is not clear.

In constructing burrows, Gunnison's prairie $\operatorname{dog}(C$. gunnisoni) leaves excavated dirt at the opening to burrows without further modification, which results in asymmetric mounds (Pizzimenti and Hoffmann, 1973; Fitzgerald and Lechleitner, 1974). Mounds usually are neither disproportionately downhill on slopes (Longhurst, 1944) nor do they have specific orientation on flat areas (Bailey, 1931; Scheffer, 1947). For burrowing mammals, size (i.e., surface area and volume) of mound varies (Vogel et al., 1973) and whether the mound at the opening to burrows correlates with size of burrow system is questionable (Butler, 2006; Schulz, 1978). Each burrow system of $C$. ludovicianus mixes ca. 200-225 $\mathrm{kg}$ of soil (Whicker and Detling, 1988). With 50-300 openings and 25-300 systems/ha (Butler, 2006) this translates to 5,000-67,500 $\mathrm{kg}$ of mixing of soil/ha. The extent of mixing of soil by 
prairie dogs is considerable in terms of processes in soil and modification of habitat (Hansell, 1993).

We examined use of mounds at openings of burrows for vigilance and mixing of soil from construction of burrows. Gunnison's prairie dogs inhabit the Four Corners region of the Southwest (Hoogland, 2003). Main goals of our study were to analyze vigilance behavior by Gunnison's prairie dog in relation to their mounds and to evaluate the magnitude of mixing of soil via building mounds.

We collected field data on four colonies JuneSeptember 2004 within Flagstaff, Coconino County, Arizona. Colonies were separated by uninhabitable urban areas. We designated study areas as ball field $\left(35^{\circ} 13^{\prime} \mathrm{N}\right.$, $\left.111^{\circ} 35^{\prime} \mathrm{W}\right)$, old cemetery $\left(35^{\circ} 12^{\prime} \mathrm{N}, 111^{\circ} 34^{\prime} \mathrm{W}\right)$, golf course $\left(35^{\circ} 12^{\prime} \mathrm{N}, 111^{\circ} 34^{\prime} \mathrm{W}\right)$, and police station $\left(35^{\circ} 11^{\prime} \mathrm{N}\right.$, $\left.111^{\circ} 39^{\prime} \mathrm{W}\right)$. Colonies were similar in population density, habitat (secondary growth, high-desert grasses and forbs), and exposure to humans and vehicular traffic.

Behavioral observations followed methods of Verdolin and Slobodchikoff (2002). We observed each colony once every 7 days for $2 \mathrm{~h}$. Two colonies were observed in the morning (0800-1100 h), and the other two colonies were observed in the afternoon (1500-1800 h). These periods correspond to bimodal activity peaks of Gunnison's prairie dog (Longhurst, 1944; Rayor, 1988). We switched morning and afternoon observations so that colonies were monitored in morning or afternoon every other day. We repeated behavioral measures for 4 weeks, providing 8 $\mathrm{h}$ of observation/colony. Observations were made over areas $10,000 \mathrm{~m}^{2}$ in size within each colony from natural elevations and blinds. Prairie dogs were not marked for identification during this study to avoid artificially increased vigilance and altered behavior. Because emergence of juveniles significantly modifies magnitude of vigilance behavior, we studied colonies after juveniles emerged from burrows (Verdolin and Slobodchikoff, 2002).

To obtain behavioral information in relation to mounds, we used binoculars and instantaneous-scan sampling (Altmann, 1974). A 30-min observation session was divided into 10 3-min sampling intervals. We classified behavior into five categories, i.e., resting-lying (lying or four feet on the ground), vigilance (Verdolin and Slobodchikoff, 2002), burrowing (digging activity at the burrow), social interaction (aggressive or amiable behavior), and other (behavior not in the four named categories and most often meant off-mound feeding). We determined whether prairie dogs were on or off the mound at each record of their behavior. We further assessed locations as high or low on the mound, or inside the opening of the burrow. We measured height of vegetation as tall $(>1 \mathrm{~m})$, medium $(1-0.5 \mathrm{~m})$, or short $(<0.5 \mathrm{~m})$ on each site by using four transects across the colony.

Orientation of vigilance behavior at the periphery and interior areas of colonies was recorded at two locations (golf course and old cemetery) using four compass directions (N, E, S, and W). We designated four subareas on each site to record vigilance behavior. We used 30-min observation sessions, divided into five 6-min intervals; this provided $2 \mathrm{~h}$ of observation/subarea. We defined the periphery as a 10-m-wide space at the edge of the colony. Using a map of the study area, we defined whether animals at the periphery looked outward from the colony, looked inward, or direction could not be determined. Examination of data for prairie dogs in the center of the colony revealed no directional bias, and data were not analyzed further.

We estimated density of burrows (openings/ha) by recording exact locations of all inhabited burrows for the $10,000-\mathrm{m}^{2}$ observation areas at each site. These areas encompassed 3-25\% of total area of colonies (police station, $25 \%$; old cemetery, $20 \%$; ball field, $6 \%$; and golf course, $3 \%$ ). A burrow was occupied if fresh soil or fresh fecal pellets were at the opening. We tallied 824 active openings across all four locations (ball field, 161 openings/ha; old cemetery, 190 openings/ha; golf course, 215 openings/ha; police station, 258 openings/ ha). To record locations of openings we used a Trimble GPS Data Logger (Trimble Inc., Sunnyvale, California) with a post-processed differential GPS for correction of data.

We estimated density of mounds and number of prairie dogs by dividing the count of inhabited burrows by three because we assumed that on average three openings belong to one burrow system (Butler, 2006; Verdolin et al., 2008). We estimated size of population by multiplying number of prairie dogs in our $10,000-\mathrm{m}^{2}$ observation areas by area of the entire colony.

For estimating size of mounds, we first measured $\geq 15$ independent, randomly chosen mounds on each study area (total $n=68$ mounds). Each mound was divided into eight equal-sized pie-sections. Volume of each pie-section was determined based on the polar-grid system, which made it possible to determine surface area of a pie-section from the pie-angle $\left(\alpha=45^{\circ}\right)$ and radius of pie-section. Knowing surface area of a pie-section, we were able to calculate volume by using the formula:

$$
\sum_{i=1}^{n}\left(\left(i d+\frac{d}{2}\right)^{2}-\left(i d-\frac{d}{2}\right)^{2}\right) \pi h_{i} \frac{45}{360}=V_{\text {pie }},
$$

where $n$ is number of measurements of height, $d$ is radius of pie-section, and $h$ is height of that section. Because the circular mound was divided into eight sections, the polar angle was always $45^{\circ}$.

Because height of mound changed from the opening to the edge of the mound, it was necessary to measure height of mound at several intervals. We placed a metal rod vertically into the ground at each opening. By means of a level, a string, and a ruler, we measured height of mound (from surface of the ground) every $10 \mathrm{~cm}$ from 
the opening to the outer edge of the mound in each piesection.

To validate calculations, we directly measured volume of pie-sections with a 1-L cylinder (accurate to $10 \mathrm{ml}$ ) for 64 pie-segments from eight mounds. We compared measured and calculated volumes of pie-segments using linear regression. From these calculations, we estimated volume and weight of a mound. We used these findings, combined with our estimates of density of burrows, to assess magnitude of mixing of soil. We used the calculation of Vleck (1981) to determine how much soil was moved to the surface during burrowing. To determine if mound and burrow were of equal size, we compared mass of a mound with the theoretical, total mass of soil removed from a burrow system of average length.

All statistics were performed using Statistica (version 8.0, www.statsoft.com). To calculate percentage of vigilant individuals, we followed Verdolin and Slobodchikoff (2002), where vigilance, $P$, was equal to $V_{a} / N_{a} ; V_{a}$ was number of prairie dogs vigilant for each observation session and $N_{a}$ was number of prairie dogs observed during each session. These values were arcsine-transformed to meet assumptions of normality. In analysis of behavioral data, repeated-measures analysis of variance was used. We used a binomial test to analyze data concerning differences in vigilance directed to the periphery versus inward toward the colony. Procedures were approved (protocol 2002-31) by the Northern Arizona University Institutional Animal Care and Use Committee.

Vigilance was significantly related to position on the mound $\left(F_{7,16}=81.72, P<0.001\right.$, Partial $\left.\eta^{2}=0.97\right)$ and height of vegetation $\left(F_{11,70}=14.16, P<0.001\right.$, Partial $\eta^{2}$ $=0.91$ ), but not to time of day (Fig. 1). Vigilance was performed most frequently on top of mounds $(P<$ $0.001)$. Proportion of individuals being vigilant increased from short to medium and tall vegetation; vigilance was greater in tall vegetation versus short vegetation $(P<$ $0.001)$ and greater in medium vegetation versus short vegetation $(P<0.01)$. Animals on the perimeter of the colony looked outward significantly more frequently than expected by chance when performing the vigilance posture (binomial test: $n=271, P<0.001$ ).

Neither volume nor surface area of mound were significantly different on the four sites $\left(F_{6,130}=1.46, P\right.$ $=0.200$, Partial $\left.\eta^{2}=0.06\right)$. Consequently, we used the composite mean (data from all four sites) of volume and surface area of mound in all calculations related to mounds. Average density of mounds was $68.7 /$ ha $( \pm 6.86$ $S E)$, with an average area of $2.092 \mathrm{~m}^{2}( \pm 0.13 \mathrm{SE})$ and volume of $0.15 \mathrm{~m}^{3}( \pm 0.02 \mathrm{SE})$, which is equal to ca. 151$242 \mathrm{~kg}$ of soil if density of soil is $1-1.6 \mathrm{~g} / \mathrm{cm}^{3}$. Taking into account only the direct effect of construction, this translates into $143.72 \mathrm{~m}^{2}$ and $10,374-16,625 \mathrm{~kg}$ of disturbance to soil on average/ha.

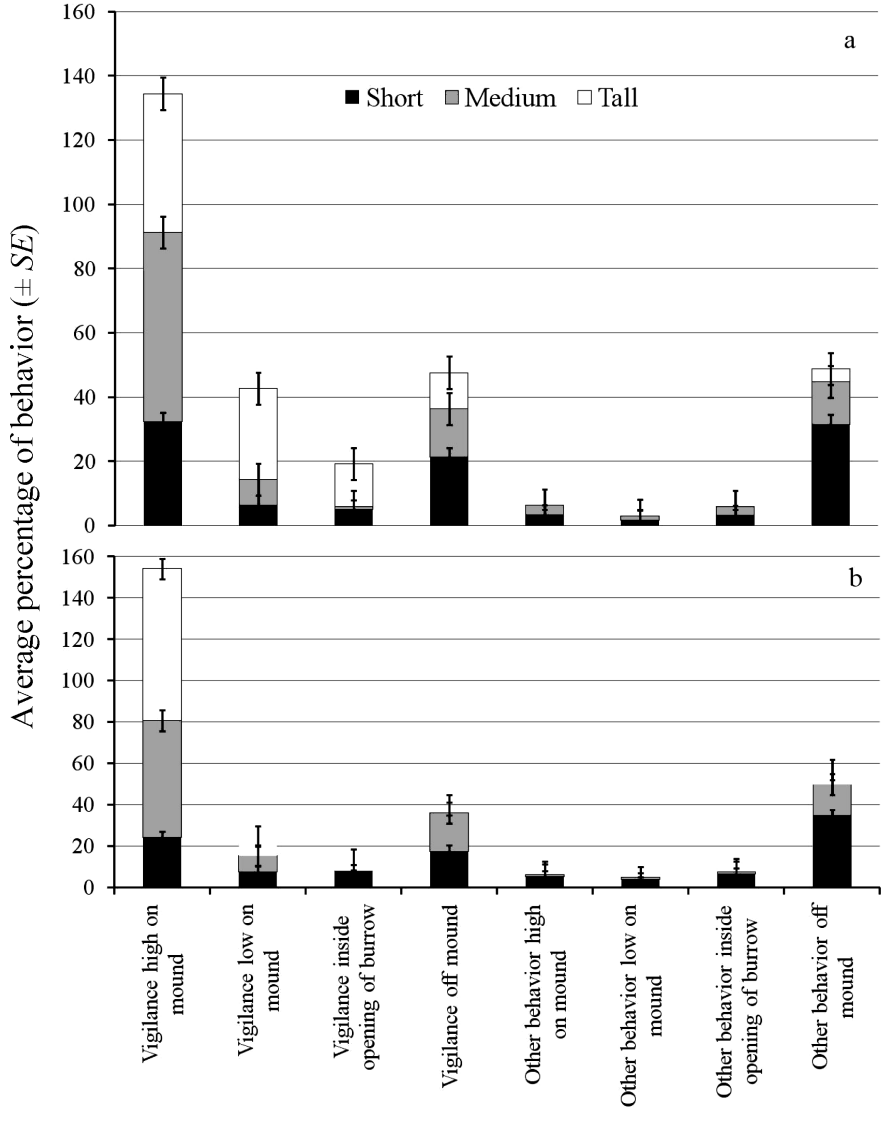

FIG. 1-Average percentage of behavior (vigilant and other) by Gunnison's prairie dogs (Cynomys gunnisoni) as a function of height of vegetation (tall, medium, short), time of day (a, morning; b, afternoon), and location of animal relative to the mound at the opening of the burrow.

Average diameter of burrow was $13.8 \mathrm{~cm}( \pm 1.3 S D)$. Gunnison's prairie dogs mix ca. 15-24 kg of soil during construction of $1 \mathrm{~m}$ of burrow. If we extrapolate from mean length of burrow in Verdolin et al. (2008), we assume that these prairie dogs mix ca. $210-335 \mathrm{~kg}$ of soil/ burrow system $(14,427-23,015 \mathrm{~kg} / \mathrm{ha})$. There was a significant positive relationship between maximum diameter and volume of mounds $\left(R^{2}=0.73, F_{1,66}=181.28, P\right.$ $<0.001)$.

We draw four conclusions. 1) Gunnison's prairie dogs use mounds for vigilance; vigilance increases with taller vegetation. The higher frequency of vigilance in situations with medium and tall vegetation indicates the ability to adapt behavior to changing natural conditions. As vegetation grows during summer, changing the rate of vigilance provides greater security. This is similar to shifts in vigilance with changes in vegetation observed in degus (Octodon degus; Ebensperger and Hurtado, 2005). 2) Vigilance is more frequent by individuals on the periphery than those in the interior of the colony, and vigilance activities by those on the periphery are directed outward from the colony (Verdolin and Slobodchikoff, 2002). It is adaptive to the colony to have an early warning 
system that is focused to potential danger from outside the colony. Ariel predators can come from any direction, but ground predators will approach the periphery. Greater vigilance by individuals living in perimeter areas that is directed outside the colony provides warnings of potential ground predators. 3) It is possible to estimate volume of burrows by measuring amount of subsoil displaced on the mound. This discovery should permit better estimation of volume of burrows and it provides a method, using the pie-shaped sections and computational formula, to achieve that end. Information on volume of burrows can be applied to situations where prairie dogs are being translocated and established in artificial burrows. 4) During construction of burrow systems, Gunnison's prairie dogs move and mix 10,000-16,500 $\mathrm{kg}$ of soil/ha, which is within the range excavated by black-tailed prairie dogs (Butler, 2006).

Effects of burrowing animals as ecosystem engineers has a significant geomorphological impact on many landscapes (Gabet et al., 2003) but measuring magnitude of bioperturbation by a population, colony, or individual is difficult (Nevo, 1999). North American pocket gophers (Geomyidae), acknowledged engineers of ecosystems, excavate ca. $18 \mathrm{~m}^{3} / \mathrm{ha}$ /year on average (Smallwood and Morrison, 1999). For Gunnison's prairie dogs, we determined that excavation of soil was $6.5-16.6 \mathrm{~m}^{3} / \mathrm{ha}$, taking into account only the volume of mounds as excavated soil. This indicates that Gunnison's prairie dogs are having an ecological impact equal to effects of pocket gophers, which provides support for statements made by Detling and Whicker (1987) and fits the ecosystem-engineer concept (Jones et al., 1994; Gutiérrez and Jones, 2006).

We acknowledge B. Birch, M. Keindl, and N. Sieben for help and advice on statistical analyses; E. Volodina, I. Volodin, A. Zareva, J. Hoogland, and D. Wagner kindly provided helpful comments on early versions of the manuscript; and A. Novák and M. Sandy translated the abstract into Spanish. Two anonymous reviewers and J. Frey provided valuable assistance in completing the final version of the manuscript. This research was supported, in part, by a Hungarian-American Fulbright Commission Scholarship to C. I. Gedeon and by the Department of Biological Sciences at Northern Arizona University.

\section{Literature Cited}

Altmann, J. 1974. Observational study of behavior: sampling methods. Behaviour 49:227-267.

Armitage, K. B. 1962. Social behavior of a colony of yellow-bellied marmot (Marmota flaviventris). Animal Behaviour 10:319331.

Bailey, V. 1931. Mammals of New Mexico. North American Fauna 53:1-412.

Butler, D. R. 2006. Human-induced changes in animal populations and distributions, and the subsequent effects on fluvial systems. Geomorphology 79:448-459.

Detling, J. K., And A. D. Whicker. 1987. Control of ecosystem processes by prairie dogs and other grassland herbivores.
Great Plains Wildlife Damage Control Workshop Proceedings, University of Nebraska, Lincoln.

Ebensperger, L. A., And M. J. Hurtado. 2005. On the relationship between herbaceous cover and vigilance activity of degus (Octodon degus). Ethology 111:593-608.

Fitzgerald, J. P., AND R. R. Lechleitner. 1974. Observations on the biology of Gunnison's prairie dog in central Colorado. American Midland Naturalist 92:146-163.

Gabet, E. J., O. J. Reichman, and E. W. Seabloom. 2003. The effects of bioturbation on soil processes and sediment transport. Annual Review of Earth and Planetary Sciences 31:249-273.

Gutiérrez, J. L., And C. G. Jones. 2006. Physical ecosystem engineers as agents of biogeochemical heterogeneity. BioScience 56:227-236.

HANSELl, M. H. 1993. The ecological impact of animal nests and burrows. Functional Ecology 7:5-12.

Hoogland, J. L. 1979. The effect of colony size on individual alertness of prairie dogs (Sciuridae: Cynomys spp.). Animal Behaviour 27:394-407.

Hoogland, J. L. 2003. Black-tailed prairie dog (Cynomys ludovicianus and allies). Pages 232-247 in Wild mammals of North America: biology, management, and conservation (G. A. Feldhamer, B. C. Thompson, and J. A. Chapman, editors). Johns Hopkins University Press, Baltimore, Maryland.

Jones, C. G., J. H. Lawton, and M. Shachak. 1994. Organisms as ecosystem engineers. Oikos 69:373-386.

KinG, J. A. 1955. Social behavior, social organization, and population dynamics in a black-tailed prairie dog town in the Black Hills of South Dakota. Contributions to the Laboratory of Vertebrate Biology, University of Michigan, Ann Arbor 67:1-123.

KInG, J. A. 1959. The social behavior of prairie dogs. Scientific American 201:128-140.

Longhurst, W. 1944. Observations on the ecology of the Gunnison prairie dog in Colorado. Journal of Mammalogy 25:24-36.

Meadows, A. 1991. Burrows and burrowing animals: an overview. Symposia of the Zoological Society of London 63:1-13.

Nevo, E. 1999. Mosaic evolution of subterranean mammals. Oxford University Press, New York.

Pizzimenti, J. J., and R. S. Hoffmann. 1973. Cynomys gunnisoni. Mammalian Species 25:1-4.

RAYOR, L. S. 1988. Social organization and space-use in Gunnison's prairie dog. Behavioral Ecology and Sociobiology 22:69-78.

Scheffer, T. H. 1947. Ecological comparisons of the plains prairie dog and the Zuni species. Transactions of the Kansas Academy of Science 49:401-406.

Schulz, K. C. A. 1978. Aspects of the burrowing system of the Cape dune mole Bathyergus suilis. South African Journal of Science 74:145-146.

Smallwood, K. S., AND M. L. Morrison. 1999. Estimating burrow volume and excavation rate of pocket gophers (Geomyidae). Southwestern Naturalist 44:173-183.

Svendsen, G. E. 1974. Behavioral and environmental factors in the spatial distribution and population dynamics of a yellowbellied marmot population. Ecology 55:760-771.

Verdolin, J. L., and C. N. Slobodchikoff. 2002. Vigilance and predation risk in Gunnison's prairie dogs (Cynomys gunnisoni). Canadian Journal of Zoology 80:1197-2003.

Verdolin, J. L., K. Lewis, and C. Slobodchikoff. 2008. Morphology of burrow systems: a comparison of Gunnison's (Cynomys 
gunnisoni), white-tailed (C. leucurus), black-tailed (C. ludovicianus), and Utah (C. parvidens) prairie dogs. Southwestern Naturalist 53:201-207.

VLECK, D. 1981. Burrow structure and foraging costs in the fossorial rodent Thomomys. Oecologia (Berlin) 49:391-396.

Vogel, S., C. P. Elington, and D. L. Kilgore. 1973. Wind-induced ventilation of the burrow of the prairie-dog, Cynomys ludovicianus. Journal of Comparative Physiology 85:1-14.

Whicker, A. D., AND J. K. Detling. 1988. Ecological consequences of prairie dog disturbances, prairie dogs alter grassland patch structure, nutrient cycling, and feeding-site selection by other herbivores. BioScience 38:778-785.

Whitford, W. G., AND F. R. Kay. 1999. Bioperturbation by mammals in deserts: a review. Journal of Arid Environments 41:203-230.

Submitted 6 May 2010. Accepted 8 May 2011.

Associate Editor was Jennifer K. Frey.

The Southwestern Naturalist 57(1): 104-105

\title{
BIG RED BAT LASIURUS EGREGIUS (VESPERTILIONIDAE) IN HONDURAS
}

\author{
José M. MorA \\ Centro Zamorano de Biodiversidad and Carrera de Desarrollo Socioeconómico y Ambiente, Escuela Agrícola Panamericana, \\ El Zamorano, Honduras \\ Correspondent: jmora@zamorano.edu
}

ABSTRACT-The big red bat, Lasiurus egregius, was known from only four localities in Panama, French Guiana, and Brazil. I report a fifth locality from eastern Honduras, extending the known range $>1,200 \mathrm{~km}$ to the northwest, well into Central America. On 9 May 1998, I captured one male and one female in a mist net near Guayabo de Catacamas, Olancho, Honduras. Both specimens were caught over water. The female was lactating and the male was reproductively inactive. This brings the total number of specimens of L. egregius to six worldwide.

Resumen-El murciélago rojo Lasiurus egregius se conocía solamente de cuatro localidades en Panamá, Guayana Francesa, y Brasil. Reporto una quinta localidad del oriente de Honduras, la cual extiende la distribución conocida más de 1,200 km al noroeste, en pleno interior de Centroamérica. El 9 de mayo de 1998 capturé un macho y una hembra en una red de seda cerca de Guayabo de Catacamas, Olancho, Honduras. Ambos especímenes fueron capturados sobre el agua. La hembra estaba lactando y el macho no presentó actividad reproductiva. Se eleva el número de especímenes mundiales de L. egregius a seis.

The big red bat, Lasiurus egregius, is a distinctive vespertilionid known from Armila $\left(8^{\circ} 41^{\prime} \mathrm{N}, 77^{\circ} 27^{\prime} \mathrm{W}\right.$; United States National Museum, USNM 11175), Provincia de San Blás, Panama; $9.5 \mathrm{~km} \mathrm{S,} 11.5 \mathrm{~km}$ W Sinnamary $\left(5^{\circ} 28^{\prime} \mathrm{N}, 53^{\circ} 00^{\prime} \mathrm{W}\right.$; Carnegie Museum of Natural History CM 88677), French Guiana; and two Brazilian records, one from Mocambo (=Belém; $01^{\circ} 27^{\prime} \mathrm{N}, 48^{\circ} 29^{\prime} \mathrm{W}$; USNM 392993), Pará, and one from an unspecified locality (Zoologisches Museum der Humboldt-Universitat zu Berlin, ZMB 3762, type specimen) in Santa Catarina, Brazil (Peters, 1871; Fairchild and Handley, 1966; Handley, 1966; Williams et al., 1990; Paynter and Traylor, 1991). Herein, I report a new locality for L. egregius from eastern Honduras, which extends its known range $>1,200$ $\mathrm{km}$ to the northwest, well into Central America.

I mist-netted bats in an extensive region of evergreen forests on 9 May 1998 near Guayabo de Catacamas $\left(14^{\circ} 43^{\prime} 130^{\prime \prime} \mathrm{N}, 85^{\circ} 22^{\prime} 720^{\prime \prime} \mathrm{W}\right.$, ca. $300 \mathrm{~m}$ elevation), Depar- tamento de Olancho, Honduras. Four 12-m-long nets were positioned inside the forest under canopy cover, near the edge of a pasture. Two of the nets were set over the Guayabo stream, ca. $50 \mathrm{~m}$ from the edge of open pasture. I captured eight bats, including two L. egregius, one of each sex. The female was captured at $1850 \mathrm{~h}$ and the male followed in the same net at $2020 \mathrm{~h}$. Both were taken at ca. $2 \mathrm{~m}$ above the stream. The moon phase was near full but did not illuminate the nets, which were in darkness at the level of the forest floor.

The female was lactating while the male was reproductively inactive. External measurements $(\mathrm{mm})$ and mass (g) of female and male, respectively, are as follows: length of head and body, 68.0, 70.0; length of tail, 62.0, 65.0; length of hind foot, 11.0, 11.0; length of ear, 18.0, 18.0; length of forearm, 50.0, 51.0; mass, 16.0, 17.0. Both specimens were prepared as study skins and skulls and are deposited at Universidad de Costa Rica (male, collector 